\title{
Clinical significance of changes in red cell distribution width during hospitalization for COVID-19
}

\author{
Alexander Yusupov ${ }^{1}$, Irma Tzur ${ }^{1}$, Chen Lin-Lasri ${ }^{1}$, Galina Plotnikov ${ }^{1}$, Osnat \\ Garach-Jehoshua ${ }^{1}$, Adina Bar-Chaim ${ }^{1}$, Dana Barchel ${ }^{1}$, and Oleg Gorelik ${ }^{1}$ \\ ${ }^{1}$ Yitzhak Shamir Medical Center Assaf Harofeh
}

November 15, 2020

\begin{abstract}
Background: The possible differences in characteristics and prognosis, among patients with coronavirus disease 2019 (COVID19), with vs. without changes in red cell distribution width (RDW) during hospitalization, have not been investigated. Methods: For 477 adults hospitalized with COVID-19, demographic, laboratory and clinical characteristics, in-hospital outcomes and allcause mortality were compared according: to high $(>14.7 \%, \mathrm{n}=146)$ vs. normal ([?]14.7\%, $\mathrm{n}=331) \mathrm{RDW}$ values at admission, and according to RDW changes $(n=150)$ vs. stable RDW $(n=262)$ during hospitalization. Results: Both high RDW at admission and change in RDW during hospitalization were significantly associated with older age, more severe clinical and laboratory characteristics, and poor in-hospital outcomes. On median follow-up lasting 83 days, the mortality rates were higher among patients with high vs. normal RDW on admission $(26.7 \%$ vs. $10.0 \%, \mathrm{P}<.001)$ and RDW changes vs. stable RDW (34.7\% vs. $5.7 \%, \mathrm{P}<.001$ ). On multivariate analysis, change in RDW was strongly associated with decreased survival (relative risk 1.50 and $95 \%$ confidence interval 1.29-1.75), while high RDW on admission was not found to be most significantly associated with mortality. Conclusions: Among patients with COVID-19, RDW changes during hospitalization were associated with a severe clinical profile, poor in-hospital outcomes and increased short-term mortality. Repeated assessment of RDW may provide useful information for improving the care of hospitalized patients with COVID-19.
\end{abstract}

\section{Hosted file}

Manuscript Version for IJCP RDW Corona Study.pdf available at https://authorea.com/users/ 375813/articles/493015-clinical-significance-of-changes-in-red-cell-distribution-widthduring-hospitalization-for-covid-19

\section{Hosted file}

Tables for IJCP RDW Corona Study.pdf available at https://authorea.com/users/375813/ articles/493015-clinical-significance-of-changes-in-red-cell-distribution-width-duringhospitalization-for-covid-19 


\begin{tabular}{|c|c|}
\hline \multicolumn{2}{|c|}{$\begin{array}{l}507 \text { patients were hospitalized with COVID-19 in a corona facility during } \\
\text { March-September } 2020\end{array}$} \\
\hline & $\begin{array}{l}30 \text { were excluded } \\
28 \text { were readmitted } \\
2 \text { were without CBC at } \\
\text { admission }\end{array}$ \\
\hline \multicolumn{2}{|c|}{477 were included } \\
\hline \multirow[t]{2}{*}{$\begin{array}{l}331 \text { had RDW values } \leq 14.7 \% \\
\text { at admission (Group 1) }\end{array}$} & $\begin{array}{l}146 \text { had RDW values }>14.7 \% \\
\text { at admission (Group 2) }\end{array}$ \\
\hline & $\begin{array}{l}65 \text { were excluded } \\
37 \text { were without last } \mathrm{CBC} \text { at } \\
\text { least } 48 \text { hours before } \\
\text { discharge } \\
28 \text { were with an interval } \\
\text { between the first and last } \\
\text { CBC of }<3 \text { days }\end{array}$ \\
\hline $\begin{array}{l}262 \text { had no significant change } \\
(\Delta \mathrm{RDW} \text { up to } \pm 0.4 \% \text { ) in } \\
\text { RDW (Group A) }\end{array}$ & $\begin{array}{l}150 \text { had significant change } \\
(\triangle \mathrm{RDW}> \pm 0.4 \%) \text { in RDW } \\
(\text { Group B) }\end{array}$ \\
\hline \multicolumn{2}{|c|}{$\begin{array}{c}\text { Demographic, clinical and laboratory variables } \\
\text { End of follow-up period - October } 2020 \\
\text { Primary outcome (all-cause mortality in the end of follow-up) } \\
\text { Secondary outcomes (in-hospital pneumonia, nosocomial infection, acute } \\
\text { coronary syndrome, venous thromboembolism, exacerbated heart failure, } \\
\text { stroke, transfer to intensive care unit, treatment with mechanical ventilation, } \\
\text { length of hospital stay and death) }\end{array}$} \\
\hline
\end{tabular}




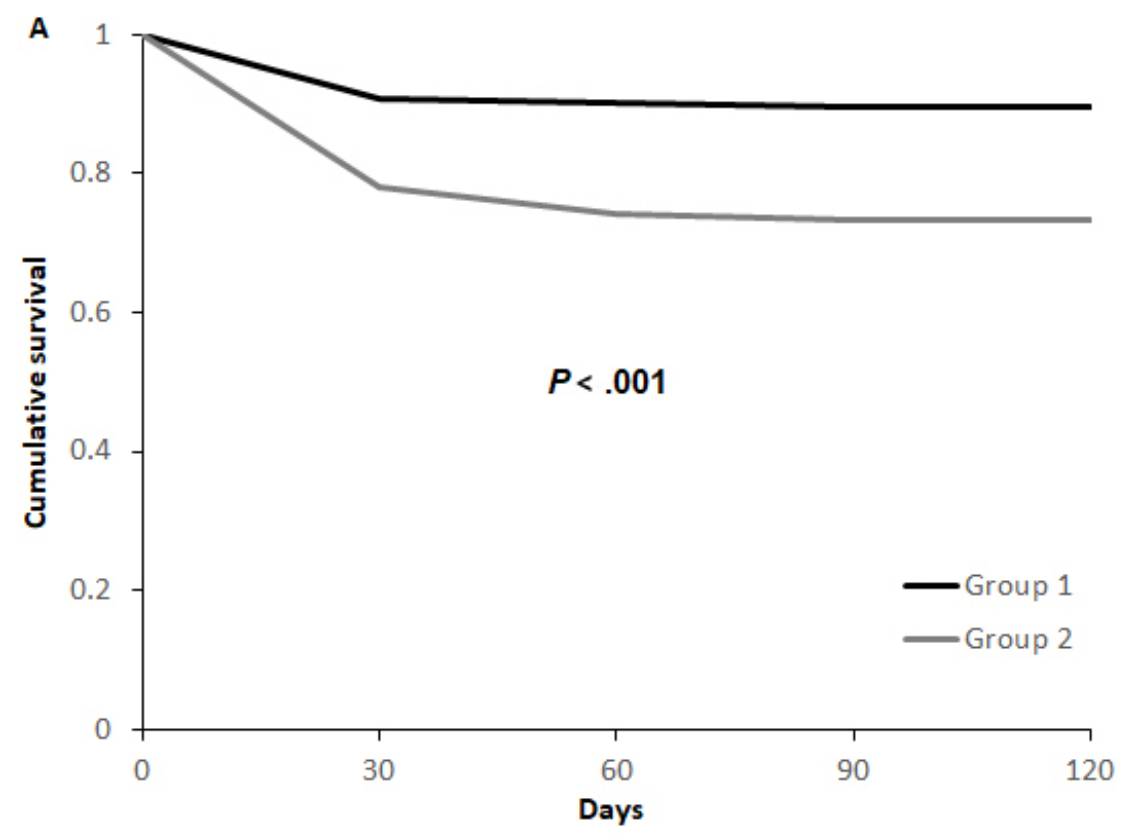

No. at Risk

Group 1331

298

239

144

82

62

93

Group 2146

113

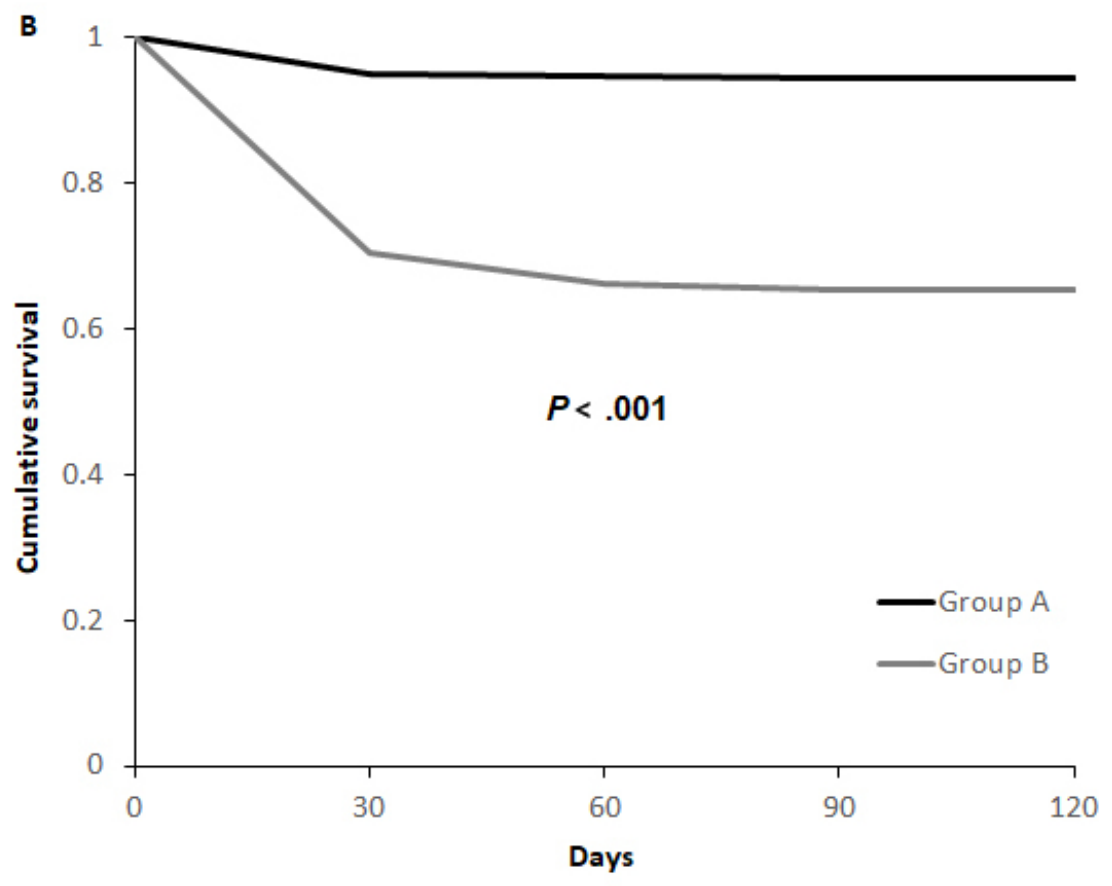

No. at Risk

Group A 262

247

105

198
77

127

69

Group B 150

(7) 